\title{
Bioethics internationally and in Austria
}

\section{A sense of solidarity}

\author{
Christiane Druml
}

Published online: 21 April 2016

(C) Springer-Verlag Wien 2016

\section{UNESCO and bioethics}

Since the 1970s, the rapid development of the life sciences, with its unprecedented possibilities to interfere with basic aspects of human life, has triggered the necessity to confront bioethical questions worldwide.

While ethics is a fundamental component of medicine and has been well integrated since ancient times, the atrocities committed by Nazi medicine have required a novel approach, which has ultimately resulted in the framework of modern bioethical standards.

For bioethics, a broad definition is mandatory: one has to include health sciences, natural sciences, and social and human sciences. Although the advances in medicine have given hope for mastering many deadly diseases and increase the quality of life of human beings, the possibilities of life sciences to interfere-especially at the beginning and end of life-have raised concern about the social, cultural, legal and ethical implications.

Thus, the interdisciplinary field of bioethics has been developed to foster such debates and raise awareness in the scientific community, but also to reflect on the issues of new technologies in an ethical discourse within the lay population.

On the occasion of the inauguration of the UNESCO Chair on Bioethics at the Medical University of Vienna, January 26, 2016

Dr. C. Druml $(\bowtie)$

UNESCO Chair on Bioethics at the Medical University of Vienna, Collections and History of Medicine of the Medical University of Vienna - Josephinum, Währingerstrasse 25, 1090 Vienna, Austria e-mail: christiane.druml@meduniwien.ac.at
When the International Bioethics Committee (IBC) of the United Nations Educational and Scientific Organisation (UNESCO) was established in 1993, UNESCO was the international pioneer, naming bioethics as one of the five priorities of its topics. This committee is composed of 36 scientists from different countries and disciplines, appointed by the Director General to advise him or her as independent experts [1].

At the same time on a national level, only France had established a National Bioethics Commission, the "Conseil Consultatif National d'Éthique", with the foresight of President Mitterrand. The reason was to discuss the progress in the life sciences: in that year the first child conceived through in vitro fertilization had been born in France and thus raised many questions in society [2].

To consider it in its entirety, one has to look at it from a historical perspective: the Constitution of UNESCO was adopted in November 1945 and affirms that "the purpose of the organisation is to contribute to peace and security by promoting collaboration among the nations through education, science and culture in order to further universal respect for justice, for the rule of law and for the human rights and fundamental freedoms".

One year later, UNESCO's first Director General Julian Huxley emphasised the importance and necessity to relate the application of science to a scale of values in order to contribute to "peace, security and human welfare": thus, since its beginnings, UNESCO has been the only specialised agency within the UN system with a mandate in the sciences and has been concerned with moral issues [3].

UNESCO's goal was ambitious, namely to develop and implement international normative standards, and the organisation is perfectly suited to do so. The United Nations Organisation (UNO) is the only plat- 
Fig. 1 From left to right: Prof. Wolfgang Schütz, Rector emeritus; Prof. Markus Müller, Rector; Christiane Druml, UNESCO Chair on Bioethics at the Medical University of Vienna; Prof. Manfred Nowak, Vice President of the Austrian Commission for UNESCO; Michael Makanga, Executive Director of EDCTP; Prof. Peter Kremsner, Universitätsklinikum Tübingen and CERMEL; Nada Al-Nashif, Assistant Director General UNESCO. (Credits: Hinterramskogler/MedUni Wien)

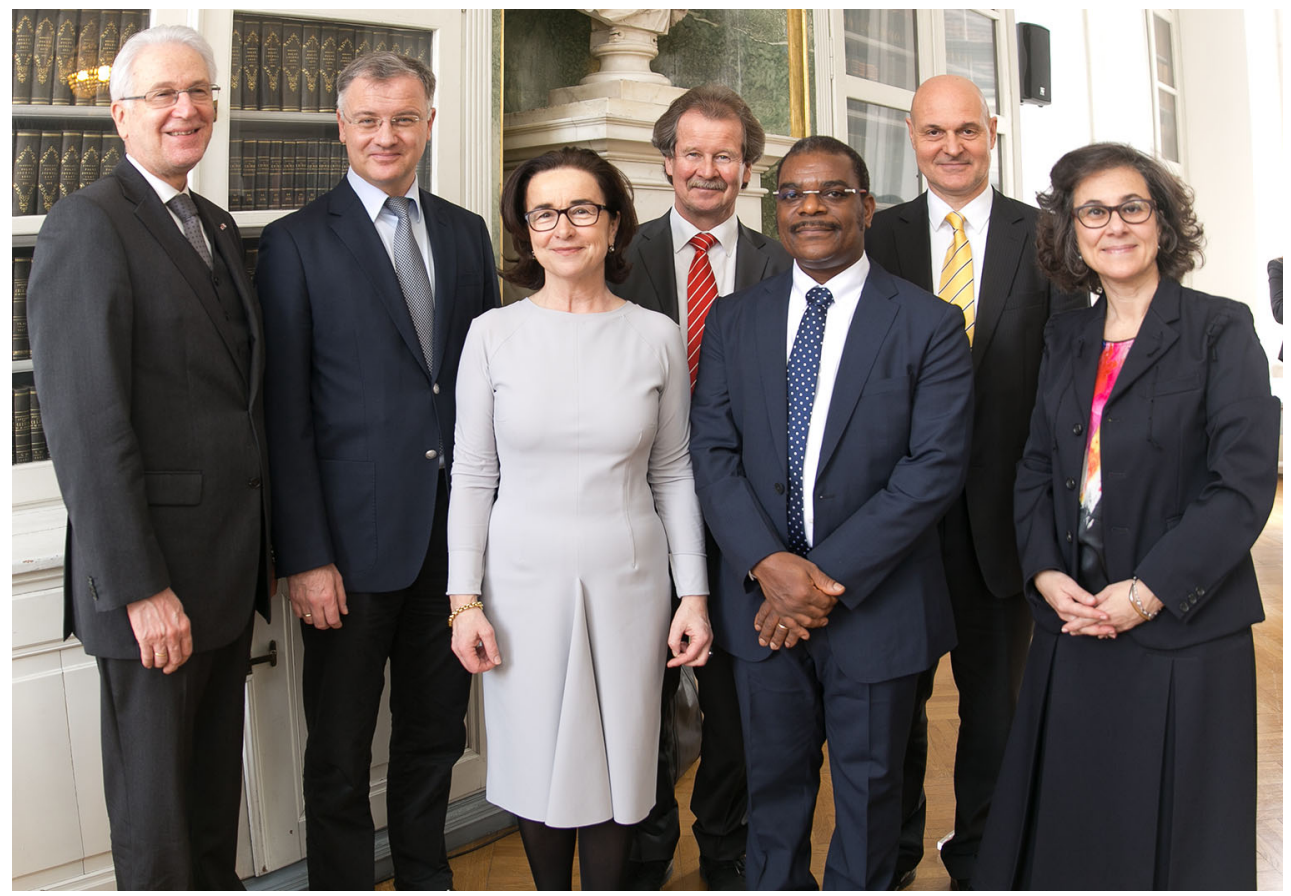

form connecting all nations of the world to explore and discuss values and principles they share. UNESCO is the only agency within the United Nations to have national bodies - the National Commissions for UNESCO-in each country. They are important as they serve as a national liaison body under the UNESCO Constitution to implement its program.

As it happens, UNESCO has published many ground-breaking documents in the field of bioethics [4]. In comparison to the work of the Council of Europe and other regional institutions like the European Group on Ethics (EGE), advising the President of the European Commission and the various National Bioethics Commissions, UNESCO has the only true perspective to do so on a global scale. Additionally, UNESCO lives the interdisciplinary nature of this quite new and academic field of bioethics in a perfect way.

In the year 2004, UNESCO's Ethics Education Program was launched with the goal of reinforcing and increasing the capacities of UNESCO's member states in the area of ethics education. One aspect is the creation of chairs in the field of bioethics.

Today-among the roughly 700 chairs worldwide for various topics-there are only five chairs in Austria at different universities. The Medical University of Vienna is proud to have inaugurated one of these at the beginning of 2016, to assist UNESCO in the implementation of the Ethics Program.

\section{Austria and bioethics}

There are two milestones with regard to the evolution of bioethics in Austria:
In the year 1993, the University of Vienna established a "Senate Institute for Ethics in Medicine", its first head was Günter Virt, a professor for moral theology of the University of Vienna. Medicine was still a faculty of the University of Vienna then-it was one of the founding faculties in 1365 and it was only 2004 that medicine became a separate university like the other medical faculties of Austria's three public universities.

Since then, the "Institute for Ethics and Law in Medicine" has been an interdisciplinary platform-carried by the faculties for Catholic and protestant theology, and the faculty of law. Although now a separate unity, the Medical University is still cooperating with the platform [5]. One result of this cooperation is the establishment of a certificate course "Ethical and Legal Aspects of Clinical Research", which is directed in particular at members of ethics committees in German-speaking countries.

\section{The Austrian Bioethics Commission}

The other milestone was the creation of the "Austrian Bioethics Commission" in the year 2001-the same year as Germany and Switzerland established their own national bioethics bodies [6]. It is to be noted that bioethics bodies have been created by governments or parliaments as advisory bodies; a movement which preceded the academic development. The national advisory bodies in bioethics are united in a network in Europe ("NEC Forum"), meeting regularly under each presidency. One of the goals of bioethics is dedicated to international exchange of information and discussion, creating an international community of scholars. 
The first Chair of the Austrian Bioethics Commission was Johannes Huber, professor for gynaecology and obstetrics of the Medical University of Vienna, who is also a doctor of theology [7]. He served as chair from 2001 to 2007.

In Austria, bioethics and the prevailing religion of Catholicism were, and still are, understood by many as inseparable. Austria is a conservative country and ethics is sometimes even seen as an "illegitimate replacement" of religion, which obviously is incorrect: ethics and religion are separate, but they share many values, like the fundamental commitment to respect human beings. However, in our societies which are increasingly globalized, ethics has to be perceived and taught in a way that common ground can be established between ethics and religion.

Since 2001, the Austrian Bioethics Commission has covered a wide range of topics reflecting burning questions regarding life sciences, medicine and society. The task of the Bioethics Commission is to "advise the Federal Chancellor from an ethical point of view on all social, scientific and legal issues arising from scientific advances in the field of human medicine and biology."

According to the decree, the commission can have up to 25 members from the different fields like medicine; molecular biology and genetics; law; sociology; philosophy; theology and psychology. The resolutions of the commission are published, including views which dissent from the majority opinion. While most of the resolutions are unanimous, subjects referring to highly sensible subjects like the beginning of life or the end of life have been published with a dissenting opinion.

An example is the debate of research on human embryonic stem cells (hESC) in the field of bioethics at the beginning of the $21^{\text {st }}$ Century. This area of research was made possible due to new techniques in the field of reproductive technology, and the debates are concentrating on the moral and legal status of the embryo in the national and international discourse. In 2009, the Austrian Bioethics Commission, with a great majority (17/25), issued an opinion determining research on embryonic stem cells to be "scientifically relevant, and in principle, morally legitimate and deserving of support", albeit being restrictive in regard to the procurement of ova. In a dissenting opinion five $(5 / 25)$ members voted for a legal ban on consuming embryo research [8]. The intensive debate of research on human embryonic stem cells of the beginning of the $21^{\text {st }}$ century has been replaced by another highly controversial development in the field of research today: the CRISPR-Cas9 technology or the ethics of human genome editing [9].

Among the 15 recommendations and opinions published by the Austrian Bioethics Commission since its beginnings in the year 2001, only eight resolutions were not unanimous. It is not surprising, as stated above, that the majority of these opinions are in the field of reproductive medicine (five), two opinions are in the field of embryonic stem cell research, and one opinion is on the topic of the end of life. Although there are some networks and single initiatives in bioethics in Austria, public debate is mainly led by the Austrian Bioethics Commission.

Neither the Institute for Ethics and Law in Medicine, nor the Austrian Bioethics Commission nor the many research ethics committees are integrated in the regular education of physicians. There are no classic institutes for ethics in medicine or bioethics at Austrian (medical) universities contributing to the curriculum of physicians on a regular and obligatory basis. This is surprising, as in a comparable area the medical faculty of the Vienna University was a frontrunner and had established the first research ethics committee (REC) in Austria very early, in the year 1978. It was the first research ethics committee in a Germanspeaking country besides the one at the University of Münster, Germany. This was short after the Declaration of Helsinki's first revision (of Tokyo) was issued, where ethics committees were recommended for the first time as an obligatory instrument to evaluate the ethical aspects of clinical research projects [10].

In Germany and other countries there is a long tradition of university institutes combining history and philosophy of medicine with ethics in medicine-a logic synergy as medical ethics and history/philosophy of medicine are the academic disciplines that engage with these issues in a basic way. These fields reflect the foundations of medicine and are areas that belong to and should be taught together. They create a specific understanding of our past, of its failures in the medical area-scandals and misuses-and illustrate our present endeavour to improve awareness for ethical principles and its efforts to codify patients' rights. Illustrative for the development of the past 50 years is the change of paradigm from paternalism to the basic principle of respect of autonomy of the patient.

Obviously, medical ethics is taught as a cross-over issue within the curriculum, but still, it is not the same as having a structured institution with senior and junior scientists and students. "There is a clear need for physicians being trained to understand the social, cultural and environmental contexts within which they will practice-in much the same way they are taught anatomy, physiology and biochemistry." In a resolution on the Inclusion of Medical Ethics and Human Rights in the Curriculum of Medical Schools WorldWide, the World Medical Association urged in 2015 that medical ethics and human rights be taught at every medical school as obligatory and examined part of the university curriculum [11].

\section{UNESCO and the first chair of bioethics at an Aus- trian university}

The establishment of a Chair of Bioethics as a joint effort of the Medical University of Vienna and UNESCO 
will set the course in the right direction. If we look into the future, 4 years from now, into the year 2020, we hopefully will see a firmly established ethics research and teaching structure at the university level. This chair could serve as a cornerstone in the direction of a constant, consistent and continuous institution in bioethics and this will have a model character for the other Austrian institutions.

There are three essential aspects:

The first aspect is teaching of graduate and postgraduate students in order to raise awareness of bioethical questions and debates, and to promote a stable and long-term bioethics program at the Medical University of Vienna. This will be done, among others, in collaboration with the Clinical Trials Coordination Centre of the Medical University of Vienna.

Additionally research ethics will be promoted in cooperation with UNESCO's Bioethics Program.

The exploration of the relevant declarations of UNESCO and their relation to the laws and soft laws in Europe, as well as the widespread dissemination of the Bioethics Core Curriculum of UNESCO will be important initiatives to foster ethics education. Training activities within UNESCO's Assisting Bioethics Committees Program will also be part of it.

An essential commitment of this Chair of Bioethics is to intensify the global reflection of ethics education with regard to North-South research, especially concerning research in poverty related diseases such as malaria, HIV, tuberculosis and other neglected infectious diseases.

The second aspect is research: what we need to do is to provide complementary and supportive research regarding ethical issues in the main research areas of the Medical University of Vienna and with the partners of the chair, additionally in the many international and European projects where a focus within a work package regarding ethics, legal and societal issues (ELSI) is required.

The third aspect will be to include "gender issues" as a cross cutting issue in this field. Bioethics is always dealing with the female body-for instance the beginning of life, reproductive medicine, stem cell research, but also clinical research-many topics which are discussed need also to be looked at from a female point of view. Furthermore, gender equality and empowering women in bioethics committees, as well as in areas of research and capacity building, is still a necessity in our societies. Special focus will be dedicated to the position of women in Africa in cooperation with the African partners of the chair.

The activities are structured in work packages:

- The short-term objectives are the organisation of seminars with the other UNESCO chairs of bioethics in Europe, as well as European members of IBC and UNESCO's Section for Bioethics and Ethics of Science and disseminate the proceedings of the seminars.
- A specific lecture (the "Josephinum" lecture) scheduled once yearly in spring will be dedicated to the UNESCO Bioethics Core Curriculum and make it better known in the German-speaking countries. The first "Josephinum lecture" will be given in spring 2017.

- Training and teaching activities with a priority to the UNESCO Bioethics Program including UNESCO's Bioethics Core Curriculum. The core curriculum will be taught yearly, during a time frame beginning in October and continuing to the end of June, starting in the academic year October 2016. The Bioethics Core Curriculum will be translated into German by summer 2016 and then be disseminated.

- Cooperation with researchers and ethicists based in Africa doing research in Africa (North-South) for capacity building and developing specific cases of research questions in African countries to be used in teaching.

\section{Partners of the chair}

UNESCO requires for the establishment of a chair "cooperation and networking to enhance institutional capacities through knowledge sharing and collaborative work". In order to fulfil this task, the chair holder made agreements with a range of institutions to cooperate:

- Research Center for Molecular Medicine of the Austrian Academy of Sciences (CeMM), Vienna, Austria,

- Ethics Platform of the University of Natural Resources and Life Sciences (BOKU), Vienna, Austria,

- College of Physicians in Vienna, Austria,

- European Forum for Good Clinical Practice (EFGCP), Brussels, Belgium,

- European Institute of Women's Health (EIWH), Dublin, Ireland,

- European Clinical Research Infrastructures Network (ECRIN), Paris, France.

An important role is given to the European and Developing Countries Clinical Trials Partnership (EDCPT). EDCTP is a partnership between 14 European and 14 sub-Saharan Africa countries that contributes to the fight against HIV/AIDS, tuberculosis, malaria and other neglected infectious diseases.

Africa is one of the global priorities of UNESCO. An essential focus of the chair is the cooperation with the network of African research centres: the "Centre de Recherches Medicales de Lambaréné”, CERMEL in Gabon; the "Fondation Congolaise pour la Recherche Medicale" in Brazzaville, Congo; the "Fondation pour la Recherche Scientifique" in Cotonou, Benin and also its Asian partner the "Institute of Clinical Medical and Pharmaceutical Sciences” in Hanoi, Vietnam.

This perspective should end with a quotation from Albert Schweitzer. This quotation, albeit simple, is, in the truest sense of the word, a motto for our society and for this Chair of Bioethics: 
The first step in the evolution of ethics is a sense of solidarity with other human beings.

The author would like to thank the following persons who have played an important role in the application process of this project (in alphabetical order): Dafna Feinholz, Michael Makanga, Charles Mgone, Markus Müller, Peter Kremsner, Wolfgang Schütz, German Solinis, Harald Stranzl, Michael Wolzt, and Eva Nowotny and Gabriele Eschig from the Austrian Commission for UNESCO.

Conflict of interest C. Druml states that there are no conflicts of interest.

\section{References}

1. Ten Have HAMJ, Jean MS. (editors) The UNESCO universal declaration on Bioethics and human rights: background, principles and application. UNESCO;2009.

2. http://www.ccne-ethique.fr/en/pages/history\#.VrxsYkb08bg. Accessed: April 8, 2016.

3. http://portal.unesco.org/en/ev.php-URL_ID $=15244 \&$ URL_DO=DO_TOPIC\&URL_SECTION=201.html. Accessed: April 8, 2016.
4. http://www.unesco.org/new/en/social-and-humansciences/themes/bioethics/international-bioethicscommittee/reports-and-advices/. Accessed: April 8, 2016.

5. http://www.ierm.univie.ac.at/ueber-uns/. Accessed: April 8,2016 .

6. https://www.bka.gv.at/site/3456/default.aspx. Accessed: April 8, 2016.

7. Gmeiner R, Körtner UHJ. Die Bioethikkommission beim Bundeskanzleramt-Aufgaben, Arbeitsweise, Bedeutung. Recht Medizin. 2002;6:164-173.

8. DrumlC.Stem cell research: toward greater unityin Europe. Cell. 2009;139(4):649-651.

9. http://www.unesco.org/new/en/social-and-humansciences/themes/bioethics/sv0/news/unesco_panel_of_ experts_calls_for_ban_on_editing_of_human_dna_to_ avoid_unethical_tampering_with_hereditary_traits/\#. VuWTE0b08bg. Accessed: April 8, 2016.

10. Druml C. 30 Jahre Ethikkommission der Medizinischen Universität Wien: Garant für integre und transparente Forschung. Wien Klin Wochenschr. 2008;120(21):645-646.

11. World Medical Association. WMA resolution on the inclusion of medical ethics and human rights in the curriculum of medical schools world-wide. Adopted by the 51st World Medical Assembly in Tel Aviv, Israel (1999) revised by the 66th WMA General Assembly, Moscow, Russia 2015. http://www.wma.net/en/30publications/ 10policies/e8/ (Created: October 2015). Accessed: April 8, 2016. 